\title{
Effect Of Nitrogen And Potassium On The Yield And Quality Of Ginger In The Derived Savanna Zone Of Obubra, Cross River State, Nigeria.
}

\author{
${ }^{1}$ Attoe, E. E., ${ }^{1}$ Undie, U. L. and ${ }^{1}$ Kekong, M.A \\ ${ }^{I}$ Department of Agronomy, Faculty of Agriculture, Cross River University of Technology, Obubra Campus, \\ Cross River State, Nigeria.
}

\begin{abstract}
The field experiment on ginger was carried out at the Derived savanna zone of Obubra which lies within latitude $06^{0} 5^{1}$ and $06^{0} 10^{I}$ North and longitude $08^{0} 21^{1}$ and $08^{0} 25^{1}$ of the Cross River State University of Technology experimental farm during the 2006 and 2007 cropping season to evaluate the response of ginger with different levels of nitrogen $(N)(0,100,200,300$ and $400 \mathrm{~kg} / \mathrm{ha})$ and potassium $(K)(0,150,100,150$ and $200 \mathrm{~kg} / \mathrm{ha}$ ). It is revealed that combined application of $N$ and $K$ was found more pronounced than the single effect of $N$ and $K$. It is also noticed that the effect of nitrogen was more distinct than $K$. The combined effect of $N$ and $K$ had significantly increased the yield and other yield contributing characters of ginger. It was also observed that $N_{300}$ and $K_{150} \mathrm{~kg} / \mathrm{h}$ a significantly augmented the ginger yield and other yield parameters. However, the highest plant height $(69.3 \mathrm{~cm}$ and $63.7 \mathrm{~cm})$, maximum number of leaves (20.5 and 18.8), leaf area $\left(39.7 \mathrm{~cm}^{3}\right.$ and $\left.36.3 \mathrm{~cm}^{3}\right)$ and total number of shoot (5.5 and 7.3) were recorded at $N_{400} K_{100} \mathrm{~kg} / \mathrm{ha}$ and were significantly different over $N_{o} K_{o}$. Similarly, rhizome yield was also significantly influenced by combined application of $N$ and $K$ up to $N_{300} K_{150} \mathrm{~kg} / \mathrm{ha}$. With highest yield (8.1 t/ha and $8.0 \mathrm{t} / \mathrm{ha}$ ) and the two years mean yield of 8.0 t/ha were recorded during the trials.
\end{abstract}

Key words: Effect of $N$ and $K$, ginger quality and yield.

\section{Introduction}

Ginger (Zingiber officinale) a popular spice crop in Nigeria has become an integral part of daily culinary preparation for its aromatic pungency scent and tasty flavor. It was mostly grown in Northern part of Nigeria but has now spread into many South-Eastern and South-Western agricultural zones of Nigeria (Okwuowulu and Ene, 1988)[1]. Ginger can be grown in wide range of soils but prefers to grown in light textured and well drained soils as it cannot grow and sustain in water-logged conditions. However, in view of the low yields of ginger in the country (5-12 t/ha) (Aliyu and Lagoke, 2000)[2] compared to 37t/ha obtained elsewhere (Whiley, 1974)[3], it is difficult to satisfy domestic consumption. Soil fertility management is a necessity in successful crop production. Therefore to increase yield of ginger, it would be necessary to supply adequate nutrients to the crop since it has a high nutrient demand.

Therefore, this study was initiated to evaluate the response of ginger to various levels of $\mathrm{N}$ and $\mathrm{K}$ for high yield potential of ginger in the Derived Savanna region, Obubra, Cross River State, Nigeria.

\section{Materials and methods}

The yield experiment was conducted at the research farm of the Cross River University of technology, Obubra Campus during the onset of the rains (April) in 2006 and 2007. The experiment location lies within latitude $06^{0} 5^{1}$ and $06^{0} 10^{1}$ North and longitude $08^{0} 21^{1}$ and $08^{0} 25^{1}$ East. The experiment was laid out in randomized block design with three replications. The unit plot size and planting distance were $3 \mathrm{~m} \times 3 \mathrm{~m}$ and $20 \mathrm{~cm} \times 20 \mathrm{~cm}$ respectively. The UGI (yellow ginger)was taken as the test crop. There were twenty-five treatment combinations each of 5 levels of $\mathrm{N}(0,100,200,300$, and $400 \mathrm{~kg} / \mathrm{ha})$ and 5 levels of $\mathrm{K}(0,50,100,150$ and $200 \mathrm{~kg} / \mathrm{ha}$ ) in the field study. The fertilizer treatments were applied in two split doses, first at 30 days after planting and the second at 90 days after planting. Ginger rhizome (seeds) weighting between $20-25 \mathrm{gms}$ were used as planting materials were planted in April 2006 and 2007 and harvested on first week in December of the two seasons. Data on different yield parameters and yield were recorded from 6 tagged plants after a quadrant (net plot) have been drawn at the middle of plots and averages found. The collected data were analyzed statistically and adjusted with least significance (LSD) at 5\% level of significance (Cochram and Cox, 1975)[4]. 


\section{Results And Discussion}

\section{Effect of Nitrogen.}

The means of observation of different parameters are presented in TABLES $2 \mathbf{a}$ and $\mathbf{2 b}$ respectively. It is revealed from the tables that $\mathrm{N}$ either in single or in combination had significant effect on the yield and other yield parameters of ginger. It is also evident that both $\mathrm{N}$ and $\mathrm{K}$ had positive impact on ginger production but the effect of $\mathrm{N}$ was found to be more distinct than the effect of $\mathrm{K}$. However, with the increase of $\mathrm{N}$ levels, other field parameters of ginger linearly increased. The yield contributing parameters progressively increased with the increase rates of $\mathrm{N}$ up to $400 \mathrm{~kg} / \mathrm{ha}$ which was significantly different over $\mathrm{N}_{\mathrm{o}}$. Here 5 levels of $\mathrm{N}$ were used in treated plots but $300 \mathrm{~kg} \mathrm{~N} / \mathrm{ha}$ responded best and the highest plant height $(63.7 \mathrm{~cm}$ and $63.0 \mathrm{~cm})$, maximum leaves number (20.5 and 16.5 per plant), leaf area $\left(34.7 \mathrm{~cm}^{3}\right.$ and $36.3 \mathrm{~cm}^{3}$ per plant) and shoot number (5.5 and 7.3 per plant) respectively in the two years of planting. Weight of ginger per plant, and ginger yield also significantly increased with the same dose of $\mathrm{N}\left(\mathrm{N}_{300} \mathrm{~kg} / \mathrm{ha}\right)$. However, the highest ginger yield $(5.7 \mathrm{t} / \mathrm{ha}$ and 8.1 $\mathrm{t} / \mathrm{ha}$ ) were obtained at the same $\mathrm{N}$ rate $\left(\mathrm{N}_{300} \mathrm{~kg} / \mathrm{ha}\right)$ in two consecutive years of study. This result was in conformity with the findings of Randhawa and Nandpori (1969)[5], Lee et al (1981)[6], and Musa (1985)[7] and the yield obtained by Orkwor et al (1988)[8] but higher than the yield reported by melifonwu and Orkwor (1988)[9]; Chuwku and Emehute (2001)[10].

\section{Effect of Potassium}

It is evident from TABLES 2a and 2b that ginger significantly responded to the different levels of K. It was also found that with the increase of $\mathrm{K}$ rates growth and other yield parameters progressively increased up to $150 \mathrm{kgk} / \mathrm{ha}$ like $\mathrm{N}, \mathrm{K}$ was also found responsive to ginger but effect of $\mathrm{K}$ was not as pronounced as $\mathrm{N}$ did. However $\mathrm{K}$ at $150 \mathrm{~kg} / \mathrm{ha}$ showed better result than that of other levels and $\mathrm{K}_{0}$. The yield attributes of ginger increased positively when $50 \mathrm{kgk} / \mathrm{ha}$ was applied in treated ginger plants. Plant height, number of leaves, number of shoot responded significantly to the K levels $(0,50,100,150$ and $200 \mathrm{kgk} / \mathrm{ha}) . \mathrm{K}$ at the highest level $(200 \mathrm{kgk} / \mathrm{ha})$ produced the highest plant height $(63.0 \mathrm{~cm}$ and $66.3 \mathrm{~cm})$, maximum leaves number $(21.8$ and 18.8$)$ plant leaf area $\left(35.0 \mathrm{~cm}^{3}\right.$ and $\left.32.0 \mathrm{~cm}^{3}\right)$, shoot number (5.2 and $7.5 /$ plant) and ginger yield significantly increased by the same dose of $\mathrm{K}(150 \mathrm{~kg} / \mathrm{ha})$ while $\mathrm{k}_{\mathrm{o}}$ produced the lowest yield. However, the highest rhizome yield (5.0t/ha and $8.0 \mathrm{t} / \mathrm{ha}$ ) and the mean yield (6.5 t/ha) of ginger was recorded at $\mathrm{K}_{150} \mathrm{~kg} / \mathrm{ha}$ and significantly differed over $\mathrm{K}_{\mathrm{o}}$ in two studied years.

Enwenzor et al (1990)[11] classified exchangeable $\mathrm{K}$ in Nigerian soils into low if $\mathrm{K}$ is less than $0.2 \mathrm{cmol} / \mathrm{hg}$, medium between $0.2-0.4 \mathrm{cmol} / \mathrm{Kg}$ and high, above $0.4 \mathrm{coml} / \mathrm{kg}$. This trend is similar to the findings of Agbede (1996)[12], he attributed the trend to the nature of the parent materials of soils in Nigeria. This may have been the reason for the high level of $\mathrm{K}$ required for ginger production in the study area.

\section{Interaction effect of $\mathbf{N}$ and $\mathrm{K}$}

Yield and yield, attributes of ginger are shown in TABLES3a and 3b respectively. The significance response on all the studied parameters where made by the combined application of $\mathrm{N}$ and $\mathrm{K}$. The study revealed that $\mathrm{N}$ and $\mathrm{K}$ in combination made a significant contribution to ginger production. But $\mathrm{N}$ and $\mathrm{K}$ in single or in combination had exhibited significant influence on yield and other yield components of ginger. But it was evident that combine effect of $\mathrm{N}$ and $\mathrm{K}$ was found more reactive than $\mathrm{N}$ and $\mathrm{K}$ did in single application. However, it was observed from two years studies that with the increase doses of $\mathrm{N}$ and $\mathrm{K}$, all the yield contributing characters increase significantly in linear way up to the level of $\mathrm{N}_{200} \mathrm{~K}_{150} \mathrm{~kg} / \mathrm{ha}$. The highest plant height $(62.5 \mathrm{~cm}$ and $63.7 \mathrm{~cm})$, maximum leaves number $(15.6$ and $16.8 / \mathrm{plant})$ and number of shoot $(5.5$ and 7.9/plant) were recorded at the highest level of $\mathrm{N}_{300} \mathrm{~K}_{150} \mathrm{~kg} / \mathrm{ha}$. Other yield contributing parameters like number of shoot and ginger yield also significantly progressed by the same treatment combination $\left(\mathrm{N}_{300} \mathrm{~K}_{150}\right)$ of $\mathrm{N}$ and $\mathrm{K}$. However, the highest rhizome yield $(6.3 \mathrm{t} / \mathrm{ha}$ and $7.8 \mathrm{t} / \mathrm{ha})$ were obtained from $\left(\mathrm{N}_{200} \mathrm{~K}_{150} \mathrm{~kg} / \mathrm{ha}\right)$ treatment combination whereas $\mathrm{N}_{\mathrm{o}} \mathrm{K}_{\mathrm{o}}$ did not give optimum ginger yield. Venkatesh et al; 1998[13] found similar results in their observations. It was revealed from the two years study that $\mathrm{N}$ and $\mathrm{K}$ at $\mathrm{N}_{200} \mathrm{~K}_{150} \mathrm{~kg} / \mathrm{ha}$ along with the blanket dose of other nutrients was found to be optimum for maximizing yield in the soils of Obubra, Cross - River State, Nigeria. So, it may be suggested that Nitrogen and Potassium at $\mathrm{N}_{200} \mathrm{~K}_{150} \mathrm{~kg} / \mathrm{ha}$ can be suitable fertilizer package for ginger production in this region.

Table 1: Nutrient Status of Experiment Soil Prior to Fertilizer Application

\begin{tabular}{|c|c|c|c|c|c|c|c|c|c|c|c|c|}
\hline \multirow{2}{*}{$\begin{array}{l}\text { Chemical } \\
\text { properties }\end{array}$} & & $\mathrm{OM}$ & $\mathrm{Ca}$ & $\mathrm{Mg}$ & $\mathrm{K}$ & $\begin{array}{l}\text { Total N } \\
\mathrm{g} / \mathrm{kg}\end{array}$ & $P$ & B & $\mathrm{Cu}$ & $\mathrm{Fe}$ & $\mathrm{Mn}$ & $\mathrm{Zn}$ \\
\hline & & \multicolumn{5}{|c|}{$\mathrm{g} / \mathrm{kg} \quad \mathrm{Cmol} / \mathrm{kg}$} & \multicolumn{6}{|c|}{$\mathrm{Mg} / \mathrm{g}$} \\
\hline $\begin{array}{l}\text { Initial soil } \\
\text { values }\end{array}$ & 5.6 & 1.93 & $\begin{array}{l}2.1 \\
4\end{array}$ & 1.56 & 0.05 & 0.06 & 25.16 & 0.70 & 1.40 & 3.6 & 11.50 & 12.90 \\
\hline Critical & - & 2.0 & 2.0 & 0.4 & 0.2 & 1.5 & 14.0 & 0.2 & 1.0 & 10.0 & 5.0 & 2.0 \\
\hline
\end{tabular}


Table 2a: Main Effect of Nitrogen and Potassium on the Yield and Yield Attributes of Ginger at Obubra, Cross River State, Nigeria (2006)

\begin{tabular}{|c|c|c|c|c|c|}
\hline $\begin{array}{ll}\begin{array}{l}\text { Nitrogen } \\
(\mathrm{kg} / \mathrm{ha})\end{array} & \text { level } \\
\end{array}$ & Plant height $(\mathrm{cm})$ & $\begin{array}{ll}\text { No. } & \text { Of } \\
\text { leaves/plant }\end{array}$ & Leaf Area $\left(\mathrm{cm}^{3}\right)$ & $\begin{array}{ll}\begin{array}{l}\text { No. } \\
\text { shoot/plant }\end{array} & \text { Of } \\
\end{array}$ & Ginger yield $\mathrm{t} / \mathrm{Ha}$ \\
\hline $\mathrm{N}_{0}$ & 39.0 & 13.3 & 21.0 & 4.8 & 4.5 \\
\hline $\mathrm{N}_{100}$ & 69.3 & 17.8 & 39.7 & 4.8 & 5.7 \\
\hline $\mathrm{N}_{200}$ & 58.0 & 13.4 & 31.3 & 4.6 & 4.7 \\
\hline $\mathrm{N}_{300}$ & 63.3 & 15.3 & 34.7 & 4.3 & 4.5 \\
\hline $\mathrm{N}_{400}$ & 63.7 & 20.5 & 32.7 & 5.5 & 4.6 \\
\hline Mean & 58.7 & 16.1 & 31.9 & 4.8 & 5.0 \\
\hline $\operatorname{LSD}_{(0.05)}$ & 4.61 & 2.54 & 7.02 & 1.08 & 1.15 \\
\hline
\end{tabular}

Effect of Potassium

\begin{tabular}{|l|l|l|l|l|l|}
\hline $\mathrm{K}_{0}$ & 39.0 & 13.3 & 21.0 & 4.8 & 4.5 \\
$\mathrm{~K}_{50}$ & 62.3 & 21.8 & 32.7 & 4.5 & 3.8 \\
$\mathrm{~K}_{100}$ & 61.3 & 20.0 & 31.0 & 5.2 & 4.6 \\
$\mathrm{~K}_{150}$ & 61.8 & 17.7 & 33.3 & 4.3 & 5.0 \\
$\mathrm{~K}_{200}$ & 63.0 & 20.9 & 35.0 & 4.7 & 4.6 \\
Mean $_{\text {LSD }}^{(0.05)}$ & 57.5 & 18.7 & 30.6 & 4.7 & 4.5 \\
& 8.8 & 2.96 & 7.25 & 1.11 & 1.22 \\
\hline
\end{tabular}

Table 2b:Main effect of Nitrogen and Potassium on the yield and yield attributes of ginger at Obubra, Cross River State, Nigeria (2007)

\begin{tabular}{|c|c|c|c|c|c|}
\hline $\begin{array}{ll}\begin{array}{l}\text { Nitrogen } \\
\text { (kg/ha) }\end{array} & \text { level } \\
\end{array}$ & $\begin{array}{ll}\begin{array}{l}\text { Plant } \\
(\mathrm{cm})\end{array} & \text { height } \\
\end{array}$ & $\begin{array}{ll}\text { No. } & \text { Of } \\
\text { leaves/plant }\end{array}$ & $\begin{array}{ll}\begin{array}{l}\text { Leaf } \\
\left(\mathrm{cm}^{3}\right)\end{array} & \text { Area } \\
\end{array}$ & $\begin{array}{ll}\text { No. } & \text { Of } \\
\text { shoot/plant }\end{array}$ & $\begin{array}{l}\text { Ginger } \\
\text { yield(t/Ha) }\end{array}$ \\
\hline $\mathrm{N}_{0}$ & 50.0 & 18.7 & 21.3 & 5.5 & 4.8 \\
\hline $\mathrm{N}_{100}$ & 60.3 & 15.6 & 19.3 & 5.7 & 6.2 \\
\hline $\mathrm{N}_{200}$ & 46.0 & 13.3 & 22.0 & 4.5 & 8.1 \\
\hline $\mathrm{N}_{300}$ & 63.0 & 16.5 & 22.0 & 7.3 & 8.0 \\
\hline $\mathrm{N}_{400}$ & 63.7 & 10.4 & 36.3 & 5.8 & 6.2 \\
\hline Mean $\operatorname{LSD}_{(0.05)}$ & 56.6 & 14.7 & 24.2 & 5.8 & 6.7 \\
\hline & 5.12 & 2.61 & 4.81 & 1.12 & 1.52 \\
\hline \multicolumn{6}{|c|}{ Effect of Potassium } \\
\hline $\mathrm{K}_{0}$ & 50.0 & 18.8 & 21.3 & 5.5 & 4.8 \\
\hline $\mathrm{K}_{50}$ & 64.0 & 11.7 & 31.3 & 9.4 & 6.5 \\
\hline $\mathrm{K}_{100}$ & 62.0 & 10.8 & 26.0 & 7.5 & 6.4 \\
\hline $\mathrm{K}_{150}$ & 63.0 & 12.6 & 32.0 & 5.9 & 8.0 \\
\hline $\mathrm{K}_{200}$ & 66.3 & 14.1 & 30.3 & 7.3 & 6.2 \\
\hline Mean & 61.0 & 13.6 & 29.2 & 7.1 & 6.4 \\
\hline $\operatorname{LSD}_{(0.05)}$ & 10.24 & 4.68 & 5.68 & 1.04 & 1.82 \\
\hline
\end{tabular}

Table 3a: Interaction effect of $\mathrm{N}$ and $\mathrm{K}$ on the yield and yield attributes of Ginger at Obubra, Cross River State, Nigeria in 2006

\begin{tabular}{|c|c|c|c|c|c|c|}
\hline $\begin{array}{l}\text { Nitrogen level } \\
\text { (kg/ha) }\end{array}$ & $\begin{array}{l}\text { K level } \\
\text { (kg/ha) }\end{array}$ & $\begin{array}{ll}\text { Plant } & \text { height } \\
\text { (cm) }\end{array}$ & $\begin{array}{l}\text { No. Of } \\
\text { leaves/plant }\end{array}$ & $\begin{array}{l}\text { Leaf Area } \\
\left(\mathrm{cm}^{3}\right)\end{array}$ & $\begin{array}{l}\text { No. Of } \\
\text { shoot/plant }\end{array}$ & $\begin{array}{l}\text { Ginger } \\
\text { yield(t/Ha) }\end{array}$ \\
\hline $\mathrm{N}_{0}$ & & 29.6 & 9.7 & 20.8 & 4.6 & 4.5 \\
\hline $\mathrm{N}_{100}$ & & 28.2 & 11.2 & 36.7 & 4.5 & 3.8 \\
\hline $\mathrm{N}_{200}$ & $\mathrm{~K}_{0}$ & 50.0 & 12.8 & 32.4 & 4.8 & 4.6 \\
\hline $\mathrm{N}_{300}$ & & 54.7 & 14.1 & 30.1 & 4.8 & 5.0 \\
\hline $\mathrm{N}_{400}$ & & 58.5 & 14.5 & 32.7 & 4.9 & 4.6 \\
\hline $\mathrm{N}_{0}$ & & 33.8 & 10.3 & 19.6 & 4.5 & 4.8 \\
\hline $\mathrm{N}_{100}$ & & 43.1 & 11.8 & 22.3 & 4.6 & 4.6 \\
\hline $\mathrm{N}_{200}$ & $\mathrm{~K}_{50}$ & 49.9 & 11.2 & 30.5 & 4.6 & 4.4 \\
\hline $\mathrm{N}_{300}$ & & 51.2 & 13.5 & 31.8 & 4.7 & 4.0 \\
\hline $\mathrm{N}_{400}$ & & 54.1 & 14.2 & 33.1 & 4.5 & 4.2 \\
\hline $\mathrm{N}_{0}$ & & 28.6 & 9.8 & 21.8 & 4.3 & 3.8 \\
\hline $\mathrm{N}_{100}$ & $\mathrm{~K}_{100}$ & 40.7 & 11.4 & 24.6 & 4.5 & 4.1 \\
\hline $\mathrm{N}_{200}$ & & 59.9 & 13.7 & 32.3 & 4.0 & 4.0 \\
\hline $\mathrm{N}_{300}$ & & 62.5 & 14.1 & 32.8 & 5.2 & 4.6 \\
\hline $\mathrm{N}_{400}$ & & 60.2 & 15.6 & 33.5 & 5.2 & 6.1 \\
\hline $\mathrm{N}_{0}$ & & 40.7 & 11.2 & 20.3 & 4.7 & 5.5 \\
\hline $\mathrm{N}_{100}$ & & 46.2 & 12.8 & 28.9 & 4.8 & 5.7 \\
\hline $\mathrm{N}_{200}$ & $\mathrm{~K}_{150}$ & 50.6 & 12.6 & 33.8 & 5.0 & 5.1 \\
\hline $\mathrm{N}_{300}$ & & 51.3 & 11.7 & 31.2 & 5.0 & 5.2 \\
\hline $\mathrm{N}_{400}$ & & 48.1 & 12.4 & 29.1 & 4.8 & 3.9 \\
\hline
\end{tabular}




\begin{tabular}{|l|l|l|l|l|l|l|}
\hline $\mathrm{N}_{0}$ & & 38.1 & 10.5 & 21.5 & 4.6 & 5.1 \\
$\mathrm{~N}_{100}$ & \multirow{2}{*}{$\mathrm{K}_{200}$} & 43.6 & 9.9 & 20.4 & 4.6 & 5.4 \\
$\mathrm{~N}_{200}$ & & 47.3 & 9.4 & 25.8 & 4.0 & 5.4 \\
$\mathrm{~N}_{300}$ & 39.1 & 10.8 & 30.1 & 4.5 & 5.6 \\
$\mathrm{~N}_{400}$ & & 9.6 & 27.6 & 4.1 & 4.8 \\
\hline LSD $_{(0.05)}$ & & 1.68 & 1.53 & 1.73 & 0.21 & 0.57 \\
\hline
\end{tabular}

Table 3b: Interaction Effect of $\mathbf{N}$ and $\mathrm{K}$ on the Yield and Yield Attributes of Ginger at Obubra, Cross River State, Nigeria in 2007

\begin{tabular}{|c|c|c|c|c|c|c|}
\hline $\begin{array}{l}\text { Nitrogen } \\
\text { level (kg/ha) }\end{array}$ & $\begin{array}{l}\text { K level } \\
\text { (kg/ha) }\end{array}$ & $\begin{array}{l}\text { Plant height } \\
\text { (cm) }\end{array}$ & $\begin{array}{l}\text { No. Of } \\
\text { leaves/plant }\end{array}$ & $\begin{array}{l}\text { Leaf } \\
\left(\mathrm{cm}^{3}\right)\end{array}$ & $\begin{array}{l}\text { No. Of } \\
\text { shoot/plant }\end{array}$ & $\begin{array}{l}\text { Ginger } \\
\text { yield } \\
\text { (t/Ha) }\end{array}$ \\
\hline N0 & & 35.7 & 10.5 & 25.3 & 4.6 & 4.5 \\
\hline N100 & & 49.9 & 10.6 & 32.1 & 5.4 & 5.7 \\
\hline N200 & $\mathrm{K}_{0}$ & 46.9 & 13.8 & 30.5 & 6.7 & 4.7 \\
\hline N300 & & 54.6 & 15.3 & 31.7 & 5.9 & 4.5 \\
\hline N400 & & 51.4 & 16.9 & 33.6 & 4.2 & 4.5 \\
\hline N0 & & 29.5 & 12.1 & 21.3 & 5.5 & 4.6 \\
\hline N100 & & 42.8 & 14.3 & 30.3 & 9.4 & 4.8 \\
\hline N200 & $\mathrm{K}_{50}$ & 58.7 & 15.1 & 26.1 & 7.5 & 4.1 \\
\hline N300 & & 61.5 & 16.9 & 22.4 & 5.9 & 4.3 \\
\hline N400 & & 62.8 & 16.5 & 30.5 & 7.3 & 3.9 \\
\hline N0 & & 28.9 & 10.3 & 33.0 & 5.0 & 5.1 \\
\hline N100 & $\mathrm{K}_{100}$ & 47.5 & 13.4 & 31.3 & 7.4 & 8.5 \\
\hline N200 & & 51.4 & 14.8 & 30.3 & 7.1 & 7.9 \\
\hline N300 & & 51.8 & 15.1 & 32.7 & 5.9 & 6.0 \\
\hline N400 & & 52.9 & 15.7 & 35.0 & 5.6 & 5.3 \\
\hline N0 & & 40.3 & 11.5 & 21.0 & 5.1 & 5.6 \\
\hline N100 & & 46.9 & 13.8 & 32.7 & 5.6 & 6.0 \\
\hline N200 & $\mathrm{K}_{150}$ & 55.1 & 14.0 & 31.0 & 6.1 & 6.5 \\
\hline N300 & & 57.8 & 15.7 & 33.3 & 6.3 & 6.9 \\
\hline N400 & & 61.9 & 16.8 & 35.0 & 6.5 & 6.0 \\
\hline N0 & & 45.1 & 12.3 & 25.0 & 5.3 & 5.7 \\
\hline N100 & & 58.6 & 12.6 & 34.0 & 5.3 & 5.4 \\
\hline N200 & $\mathrm{K}_{200}$ & 50.1 & 14.5 & 25.3 & 5.5 & 5.1 \\
\hline N300 & & 52.7 & 16.3 & 23.3 & 5.6 & 5.2 \\
\hline N400 & & 62.8 & 16.8 & 29.7 & 5.6 & 6.1 \\
\hline $\operatorname{LSD}_{(0.05)}$ & & 1.82 & 1.41 & 1.63 & 0.23 & 0.54 \\
\hline
\end{tabular}

\section{References}

[1]. Okwuowulu, P. A. and Ene, L. S. O. Exploited Plant: The Edible Ginger (Zingiber Officinale Roscoe). In: Proceeding of the first National ginger workshop. Oct. 17-21, 1988, Umudike, Nigeria. Pp 59-62.

[2]. Aliyu, L. and S. T. O. Lagoke. Profitability of Chemical Weed Control in ginger (ZingiberOfficinale Roscoe) Production in Northern Nigeria. (Crop Protection Elsevier Science Ltd, 2000).

[3]. Whiley, A. W. Ginger growing in Queensland. Queensland Agricultural Journal, 100, 1974,551-557.

[4]. Cochram, W. G. and Cox, G. M. Experimental Design. (John Wiley and Sons Inc. NY ,1975). Pp 612.

[5]. Randhawa, K. S. and Nandpori, K. S. Response of ginger (Zingiber officinale) to N, P, and K. fertilizer.

[6]. Lee, M. T., Asher, C. J. and Whiley, A. W. Nitrogen nutrition of ginger (Zingiber Officinale). Effects of nitrogen supply on growth and development. Field crops research $4,1981,55-68$.

[7]. Musa, U. B. The effect of Nitrogen and Phosphorus on the growth and yield of ginger (Zingiber Officinale Roscoe). Unpublished M/Sc. Thesis, Ahmadu Bello University, Zaria, Nigeria, 1986. 74 pages.

[8]. Orkwor, G. C. Arene O. B; Okonkwo, J. C. and Oparah, U. L. A. Studies on the agronomic practices in ginger (Zingiber Officinale Roscoe), Production in the Northern Guinea Savannah and the Rainforest zones of Nigeria In: Proceeding of the first National Ginger Workshop Oct. 17-21, 1988, Umudike, Nigeria. Pp $43-50$.

[9]. Melifonwu, A, A. and Orkwor G. C. Weed Management in edible ginger (Zingiber Officinale Roscoe) Production from Minisetts. In : Proceeding of the first National Ginger Workshop Oct. 17 -21, 1988, Umudike, Nigeria. Pp 51-58.

[10]. Chukwu, G. O. and Emehute, J. K. U. Effect of NPK fertilizers and Cuttivar on edible ginger growth and yield at Umudlike, Nigeria. J. Sustain Agric. Environ. 3(1), 2001, 193-198.

[11]. Enwenzor, W. O., Ohiri, A. C. Opuwaribo, E. E. and Udo, E. J. Literature review on soil fertility investigation in Nigeria. FPPD, Lagos, Nigeria, 1990.

[12]. Agbede, O.O. Comprehensive analysis of the Chemistry and Mineralogy of some Nigerian derived Savannah and rainforest soils. In: African soils. Proceeding of the $3^{\text {rd }}$ African Soil Soc. Conference Ibadan, Nigeria, 1996, $183-200$.

[13]. Venkatesha, J. Khan, M. M. and Farooqi, A. A. Effect of major nutrients (NPK) on growth yield and quality of turmeric cultivators.Proceedings of Nation seminar, Madikeri, Karnataka, India. 5 - 6 October, 1997. 